\title{
Continuing the work of the late Dr Mahmoud Fikri, WHO Regional Director for the Eastern Mediterranean
}

\author{
Jaouad Mahjour ${ }^{1}$
}

It was with terrible shock and profound sadness for all to learn that DrMahmoud Fikri, WHO Regional Director for the Eastern Mediterranean, tragically died of a heart attack on 17 October 2017 , as he was en route to Uruguay to attend the WHO Global Conference on Noncommunicable Diseases (1). Dr Fikri had been appointed as Regional Director in January 2017 by WHO's Executive Board following his nomination by the Regional Committee for the Eastern Mediterranean in October 2016. He had taken office on 1 February, 2017 (2).

Despite the short time that he served as Regional Director, Dr Fikri was determined to position $\mathrm{WHO}$ as a leading and respected health partner and had developed a roadmap that translated his vision into a set of strategic actions to guide WHO's work in the Region over a 5-year period. This document, entitled "Roadmap of WHO's Work for the Eastern Mediterranean Region 2017-2021" (3), placed emphasis on five priorities - emergencies and health security; communicable diseases; noncommunicable diseases; maternal, neonatal, child and adolescent health; and health system strengthening - in line with the Sustainable Development Goals 2030, and the global vision of WHO's Director General.

Dr Fikri recognized WHO's staff as the Organization's greatest resource and was committed to providing a productive, creative and innovative environment, in order to establish WHO as a centre of excellence in the Region. They will remember him for his modesty, sense of humour, kindheartedness and compassion and for his recognition of the unique and important role played by every single member of staff in the Region. In his first week in the Regional Office, he made a point of visiting each staff in their office to meet them personally and shake their hand. During each of his country visits, he met with all WHO staff to acknowledge and appreciate their contribution to WHO's work. He was committed to creating an environment where every member of staff felt protected, valued and part of a team, and took every opportunity to host events that reinforced a sense of team spirit.

As a priority, Dr Fikri made visits to many countries of the Region to see first-hand the situation on the ground. He attended Somalia's celebration of its 3 years' polio-free certification in the presence of H.E. Mohamed Abdullahi Mohamed, President of Somalia. He also held talks with heads of states and governments and top officials in Djibouti, Egypt, Iraq, Islamic Republic of Iran, Jordan, Lebanon, Oman, Pakistan, Sudan, Tunisia, United Arab Emirates and Yemen, with a view of establishing new strategic relations, in which countries and WHO shared the responsibility of addressing public health issues, responding to humanitarian emergencies, and developing and implementing policies to promote the health of all populations in the Region.
Dr Fikri has left a strong foundation for WHO's continuing work in the Region. Shortly before his death, the $64^{\text {th }}$ Session of the Regional Committee for the Eastern Mediterranean had concluded in Islamabad, Pakistan. It had been attended by H.E. Mamnoon Hussain, President of Pakistan. It was the first time for the president of a country to attend a session of the Regional Committee, and the meeting attracted great political, diplomatic and media attention. In sharing his vision for WHO in the Region, Dr Fikri had said that health was the smartest thing to invest in and yielded high returns and progress would only be possible through the sustained commitment of Member States and international, local and development partners. He pledged to unite efforts, drawing on particular strengths and resources to ensure holistic improvements to health. The Regional Committee in 2017 endorsed a number of resolutions on cancer, climate change, the health of adolescents and antimicrobial resistance that will have a positive impact on the health of populations in countries of the Region.

Dr Fikri was a unique leader and a good listener who will be missed by staff, colleagues and all those who were fortunate enough to meet him. WHO staff of the Eastern Mediterranean Region have pledged to take Dr Fikri's roadmap forward as his legacy and to fulfil his vision for WHO's work with countries in the Region. 


\section{References}

1. World Health Organization. WHO global conference on noncommunicable disease: enhancing policy coherence between spheres of policy making that have a bearing on attaining SDG target 3.4 on NCDs by 2030. Geneva: World Health Organization; 2017 (http://www.who.int/nmh/events/2017/montevideo/about/en/, accessed 4 December 2017).

2. WHO Regional Office for the Eastern Mediterranean. Mahmoud Fikri appointed as regional director for the WHO Eastern Mediterranean Region. Cairo: WHO Regional Office for the Eastern Mediterranean; 2017 (http://www.emro.who. $\mathrm{int} / \mathrm{media} /$ news/mahmoud-fikri-from-united-arab-emirates- appointed-as-who-regional-director-for-the-eastern-mediterranean.html, accessed 4 November 2017).

3. WHO Regional Office for the Eastern Mediterranean (EMRO). Roadmap of WHO's work for the Eastern Mediterranean Region 2017-2021. Cairo: EMRO; 2017 (http://applications.emro. who.int/docs/EMROPUB_2017_19695_EN.pdf, accessed 4 December 2017). 